\title{
Ectoparasites infesting rats at mostorod and bahteem Districts in Qualubiya Governorate, Egypt
}

\author{
Mohammad K. Yassin \\ Department of Zoology, Faculty of Science, Al-Azhar University, Nasr City, Cairo, \\ Egypt \\ e.mail:koriem@live.com
}

\section{ABSTRACT}

The present research was carried out to study ecto-parasites infesting rats at Mostorod and Bahteem districts, Qaliubiya Governorate, during 2008 from may till October. Three rat species parasitized by ectoparasites, $R$. Rattus rattus having the highest number of parasites (54.5\%). This was followed by $R$. norvegicus $(29.5 \%)$, and Mus musculus (16.0\%) Although Mus musculus did not show a high infestation rate compared to Rattus rattus or $R$. norvegicus, it harbored seven species of parasites. Rattus rattus and $R$ norvegicus had six species of ectoparasites recovered.

The identified ectoparasites isolated from skin and hair of rats based on their morphological characteristics were: Polyplax spinulosa (43.6\%),Laelaps nuttali (23.5\%), Polyplax serrata (11.3), Ornithonyssius bacoti (10.3\%), Dermanyssus sanguineus (7.3\%),Dermanyssus americanus (2.8)and Rhipicephalus sanguineus. (1.3).The infestation rate of the parasite varied based on the rat species, $R$. rattus having the highest infestation rate. Polyplax spinulosa parasitized predominantly $R$. rattus, while Laelaps nuttali and Ornithonyssius bacoti ware found mainly on $R$. norvegicus. Dermanyssus sanguineus was predominantly $R$. rattus, and Mus musculus, while Dermanyssus americanus was found mainly on $R$. rattus. Polyplax serrata was found on $R$. rattus $R$. norvegicus, and Mus musculus while Rhipicephalus sanguineus was only recovered on Mus musculus. Ectoparasite infestation was also influenced by the sex of the host, with male rats (73.7\%) manifesting a significantly higher $(\mathrm{p}<0.05)$ infestation rate than female rats $(26.3 \%)$.

All recovered ectoparasites were common parasites of rats. Infested rats near human habitations in the area warrant possible rodent-borne diseases among the residents thus, an investigation of the occurrence of rodent-borne diseases among the dwellers may provide epidemiologic pattern related to such diseases including vectors of zoonotic diseases.

Keywords: Ectoparasites, infesting rats, at mostorod and bahteem

\section{INTRODUCTION}

Rodents are one of the main health problems, especially in low hygienic level and densely populated in addition to areas having non-covered drainage channels, rubbish, wastes and some cultivated lands. Rats are very common in many Egyptian Governorates (Shoukry et al.., 1987) since most of the rodent species are reservoir for many zoonotic diseases. Their ectoparasitic fauna become of special interest due to their active role in transmission and dissimination of serious pathogens to man and his domestic animals (Urceuhart et al.., 1994 Nava et al., 2003). A number of vertebrate animals will invade domestic and commercial premises in search of food and shelter. In doing so, they may be involved in the transmission of disease, soiling and 
destroying commodities and packing, damaging equipments, buildings and installations, and causing a nuisance. Rodents are the most important animal in this view (Burgess, 1998). They are the largest order of mammals, representing $43 \%$ of specific global mammalian diversity, and including 443 genera and 2021 different species (Saluzzo and Dodet, 1999). The diversity and infestation variations in ectoparasites among wild rodents may indicate the prevalence of representative parasites on their hosts and may reflect their host specificity required for their survival and proliferation (Soliman et al., 2001b). They also noted that environmental conditions, such as season, topography and vegetation can affect rodent hosts and their ectoparasites (Soliman et al., 2001a). Rodents together with arthropod ectoparasites can play an important role in distribution of the arboviruses, streptococcal infections, choriomeningitis, plague, tularemia, leptospirosis, as carriers /reservoir spirochaetosis, etc (Mansan and Stanko, 2005). Taking into account the role of rodents hosts of disease-carrying agents (Harkness and Wagner, 1989) and their close proximity to human habitations (Nowack, 1991; Salibay and Claveria, 2005), Some ectoparasites may also act as vectors of viruses, rickettsia, bacteria, protozoa, cestodes and nematodes, including vectors of zoonotic diseases in humans (Arends et al., 1990; Uilenberg, 1995; Raoult and Roux, 1997; Singleton et al., 2003 Parola et al., 2003, 2005; Rehbein et al., 2003; Petney et al., 2007; and Ahantarig et al., 2008).

\section{MATERIALS AND METHODS}

This study was conducted in two districts (Bahteem and Mostorod) at Qaliubiya Governorate, during 2008 from May till October. Rats were captured from different parts of the two districts using wire- box traps with spring-door. In both districts 20 spring door wire traps with food bait, which included bananas, grilled coconut meat, and dried fish were deployed with an interval of 5 meters for each collection site. The traps were set before dusk and checked in the early morning. In the absence of a rodent, traps with fresh bait were left in place for two to three days, and then transferred to another location. Since some ectoparasites leave the body of the host shortly after death, the captured rodents were transferred from the cages to closed containers before the euthanization process to ensure the collection of the ectoparasites present on the body of the euthanized hosts. Under open-air field conditions or well-ventilated areas, chloroform was appropriated for euthanization since it also kills ectoparasites. Collected rodents were processed with formalin and preserved in glass jars with $70-80 \%$ ethanol. and transported to the laboratory, their morphometric characters were recorded for following identification (Etemad, 1978) and ectoparasites were recovered by combing their body hairs with a toothbrush on the water surface, pick up with fine needle from the water and conserved in ethanol $70 \%$. They were mounted on permanent slides following the conventional techniques for each group and then identified using different keys (Johnson, 1960; Farhang-Azad, 1970; Baker, 1999).

\section{RESULTS}

Seventy sex rodents demonstrated three species were captured: Rattus rattus represented (54.5\%), $R$ norvegicus. (29.5\%), and Mus musculus (16.0\%), the first and second species belong to the genus Rattus, while the third belongs to the genus Mus as in the following table (1). 
Table 1: Fauna of ecto-parasites and rodent species at Bahteem and Mostorod, during 2008 from May till October.

\begin{tabular}{|c|c|c|c|c|c|c|c|c|c|}
\hline \multirow{2}{*}{$\begin{array}{c}\text { Total } \\
\text { No. of } \\
\text { Rat species }\end{array}$} & \multicolumn{7}{|c|}{ Number of Ectoparasite species present } & \multirow{2}{*}{ Total } & \multirow{2}{*}{$\%$} \\
\hline & $\begin{array}{l}\text { Rhipice. } \\
\text { Sangu. }\end{array}$ & $\begin{array}{c}\text { Ornith. } \\
\text { bacoti }\end{array}$ & $\begin{array}{l}\text { Laela. } \\
\text { nuttali }\end{array}$ & $\begin{array}{l}\text { Derm. } \\
\text { ameri. }\end{array}$ & $\begin{array}{c}\text { Derm.s } \\
\text { ang.. }\end{array}$ & $\begin{array}{l}\text { Polyl. } \\
\text { Spinu. }\end{array}$ & Polyp.serra. & & \\
\hline Rattus rattus (36) & 0 & 15 & 32 & 7 & 16 & 165 & 20 & 255 & 54.5 \\
\hline R. norvegicus (26) & 0 & 30 & 57 & 3 & 5 & 26 & 17 & 138 & 29.5 \\
\hline Mus musculus (14) & 6 & 3 & 21 & 3 & 13 & 13 & 16 & 75 & 16.0 \\
\hline Total & 6 & 48 & 110 & 13 & 34 & 204 & 53 & 468 & \\
\hline$\%$ & 1.3 & 10.3 & 23.5 & 2.8 & 7.3 & 43.6 & 11.3 & & \\
\hline
\end{tabular}

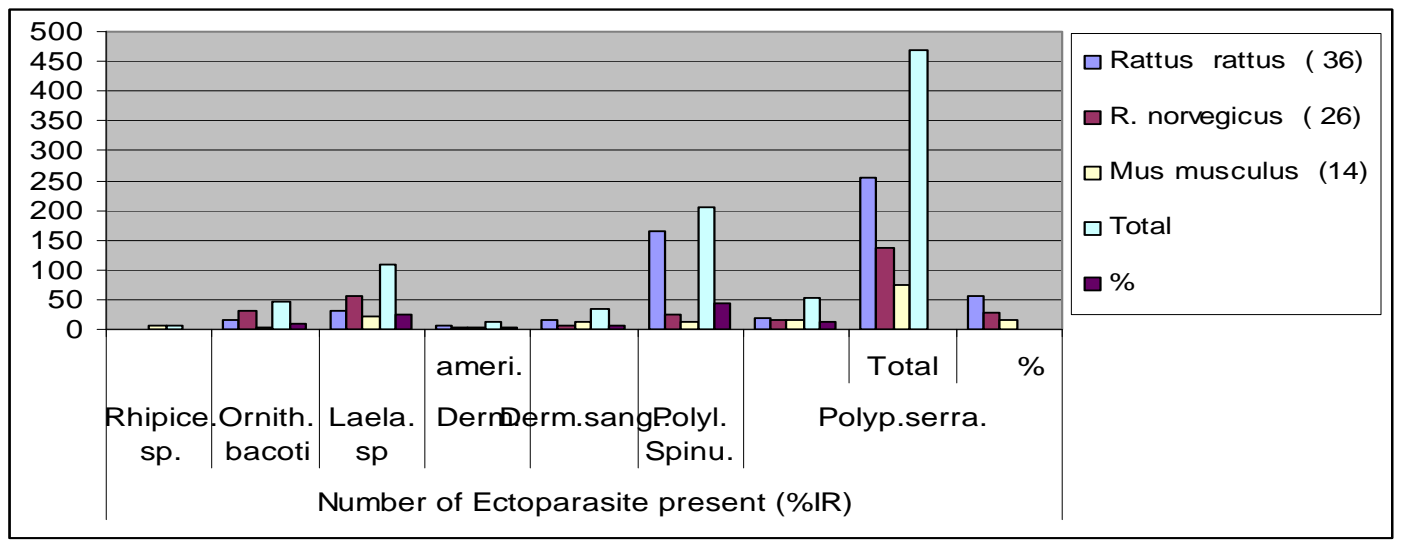

Fig. 1: Ecto-parasites in relation to rodent species at Bahteem and Mostorod, during 2008 from may till October.

Table 2: No. of infested rats in relation to sex

\begin{tabular}{|l|cc|cc|}
\hline \multirow{2}{*}{ Rat species } & \multicolumn{4}{|l|}{ No. of infested rats in relation to sex (\%) } \\
\cline { 2 - 5 } & Males & $\%$ & Females & $\%$ \\
\hline R. rattus & 25 & $(32.9)$ & 11 & $(14.5)$ \\
\hline R. norvegicus & 21 & $(27.6)$ & 5 & $(6.6)$ \\
\hline Mus musculus & 10 & $(13.2)$ & 4 & $(5.3)$ \\
\hline Totals & 56 & 73.7 & 20 & 26.3 \\
\hline
\end{tabular}

$\mathrm{p}<0.05$ (highly significant)

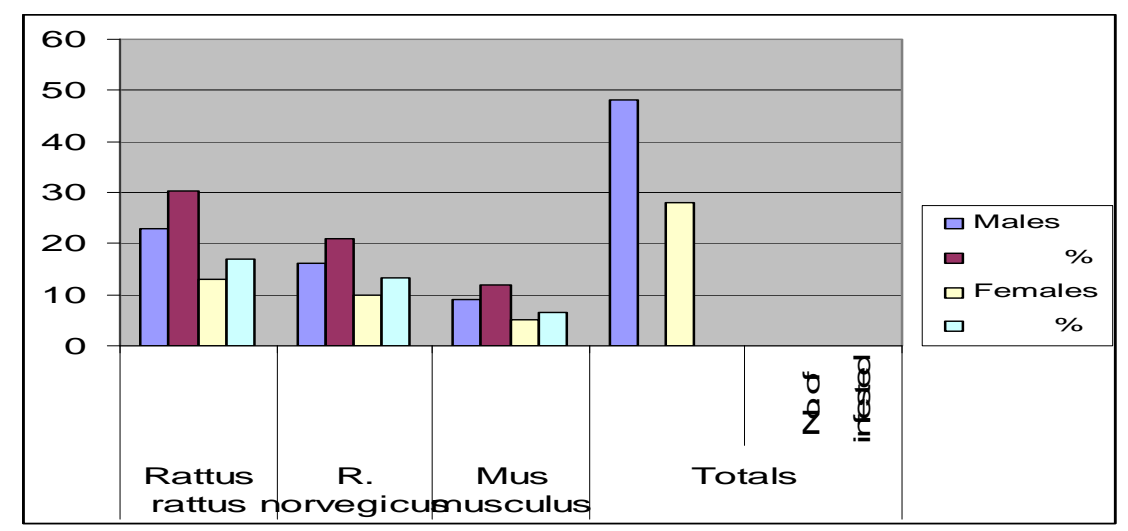

Fig.2: No. of infested rats in relation to sex

The number and species of ectoparasites recovered from the rats are presented in Table (1). The results indicate all rats collected were parasitized by ectoparasites, with $R$. rattus having the highest number of parasites recovered $(54.5 \%)$. This was followed by $R$. norvegicus (29.5\%), and Mus musculus (16.0\%). Although Mus musculus did not show high infestation rate compared to $R$. rattus or $R$. norvegicus, it harbored seven species of parasites. $R$. rattus and $R$. norvegicus had the least number of types of ectoparasites recovered. 
Two species of ectoparasites of the class Insecta and five species of class Arachnida were collected from the rodents (Fig 1). Of class insecta, the two spined rat louse, Polyplax spinulosa and Polyplax serrata (43.6\% and11.3\%, respectively), dominated the infestation of all rodents. However, Rhipicephalus sanguineus $(1.3 \%)$ was recovered only on Mus musculus, and with a minimal infestation rate.

Of the arachnids recovered, the two scab mites, Dermanyssus sanguineus and Dermanyssus americanus constituted $7.3 \%$ and $2.8 \%$, respectively of the collected rats, with the highest infestation rate being in $R$. rattus, followed by Mus musculus and $R$. norvegicus The common rat mite, Laelaps nuttali had on $23.5 \%$ infestation rate, which was also recovered from the three hosts but, most frequently in $R$. norvegicus, followed by $R$. rattus then Mus musculus. The tropical rat mite, Ornithonyssus bacoti (10.3\%) infested both $R$. norvegicus and $R$ rattus. Ectoparasite infestation relative to host sex was significantly higher $(\mathrm{p}<0.05)$ in male rat than in females (Table $2 \&$ Fig. 2). This may be due to the fact that male rats are bigger in size and are more active so that they have high chances of being infesteds.

\section{DISCUSSION}

The present study revealed two ectoparasites from class Insecta and 5 from class Arachnida, most of which are ectoparasites on Rattus species (Harwood and James, 1979 and Gratz, 1988). Similar to earlier surveys (Durden and Page, 1991 and Soliman et al., 2001a,b) of ectoparasites on commensal murid rats, these are known to be found on Rattus spp., and are not classified as being host specific (Soulsby, 1982 and Walker, 1994). This was evident with P. spinulosa found in all rat species collected, which may be indicative of rat-to-rat transmission within and among the different species of hosts. The findings of this study are similar to those in studies by Durden and Page (1991) and Soliman et al. (2001b) of the presence of mites on rodents. They collected L. echidnina, L. nuttali and O. bacoti; X. cheopis; and Hoplopleura pacifica and P. spinulosa from R.r.palelae, R. argentiventer, R. exulans and M.m. castaneus, in Sulawesi Utara, Indonesia (Durden and Page, 1991), and R. norvegicus and $R$. rattus from rural Egypt (Soliman et al., 2001b). Both studies indicate that $L$. nuttali, $O$. bacoti, $X$. cheopis and $P$. spinulosa were associated with murid rodents, especially Rattus species. Of the Rattus species, $R$. argentiventer is considered important in the maintenance of campestral or sylvatic plague caused by fleas associated with field rodents. This may cause such disease in rural areas even if there is no outbreak of plague cases (Nava et al., 2003; Singleton et al., 2003 Parola et al., 2003, 2005; Rehbein et al., 2003; Petney et al., 2007; and Ahantarig et al., 2008). A study done by Gratz (1988) proved that the chances of encountering Rattus species varried depending on the rat's habitat preference. Their preferences may be influenced by their food sources.

The high infestation rate of ectoparasite species in Rattus rattus and $R$. norvegicus can be attributed to these species preference for more congested areas where houses and some agricultural areas are located (Sanchez et al., 1985) compared to Mus musculus, which dwells only in areas near its habitat with less disturbance caused by the presence of human settlements (Sanchez et al., 1985; Heaney et al., 1999). This result is in a greater chance for a physical encounter among rat species in congested areas, and the transfer of ectoparasites from one host to another, as in the case of $R$. rattus and $R$. norvegicus in this study.

In natural forest conditions, rats in the wild are considered to be cleaner (Heaney and Regalado, 1998) compared to those that are found in urban areas (Salazar, 1977). 
This is because rat species dwelling in forests consume fruits or crops, while those dwelling in urban areas are found in poorly sanitized areas and in nearby garbage dumpsites. Salazar (1977) also noted rat species caught in urban areas had poorer hygiene. In this study, some rats recovered in the cultivated areas were of the same species as those in urban dwellers.

In conclusion, although, the degree of infestation of ectoparasite varies among the host species, the elevation and habitat where the species were collected did not show direct influence as to the infestation rate of the ectoparasites.

\section{REFERENCES}

Ahantarig, A.; Trinachartvanit, W. and Milne, J.R. (2008): A review of tick-borne pathogens and disease of animals and humans in Thailand. Southeast Asian $J$ Trop Med Pub Health 39: 1015-32.

Arends, J.; Stanislaw, C. and Gerdon, D. (1990): Effects of sarcoptic mange on lactating swine and Growing pigs. J Anim Sci; 68: 1495-9.

Baker, A. S. (1999): Mites and ticks of domestic animals. London: Natural History Museum Publication, 240 pages.

Burgess, N. R. H. (1998): Public health pests, a guide to identification, biology and control, Chapman and Hall, 176 pages.

Durden, L. A. and Page, B. F., (1991): Ectoparasites of commensal rodents in Sulawesi Utara, Indonesia, with notes on species of medical importance. Med. Vet. Entomol., 5(1): 1-7.

Durden, L. A. and Page, B. F. (1997): Ectoparasites of commensal rodents in Sulawesi Utara, Indonesia, with notes on species of medical importance. Med. Vet. Entomol. 5:1-7.

Etemad, E. (1978): Mammals of Iran, Vol 1. Rodents and their Identification Keys. Tehran: Natural Society of Guardianship of National Resources and Human Environment. 286 pages.

Farhang-Azad, A. (1970): The flea fauna of Iran, IX. Distribution and hosts. Bull. Soc. Path. Exot., 1: 107-126.

Gratz, N. G. (1988): Rodents and human disease: A global appreciation. Rodent Pest Management. Boca Raton, Florida: CRC Press.45-9.

Harkness, J. E. and Wagner, J. E. (1989): The biology and medicine of rabbits and rodents. $3^{\text {rd }}$ ed. Philadelphia: Lea \& Febiger Publications: 230 pp.

Harwood, R.F. and James, M. T. (1979): Entomology in human and animal health, $7^{\text {th }}$ ed. New York: Macmillan Pub. 548 pp.

Heaney, L. R. and Regalado, J.r. J.C (1998). Vanishing treasures of the Philippine rain forest:The Field Guide Museum Chicago: Field Museum of Natural History.88 pp.

Heaney, L. R.; Balete, D.S.; Rickart, E. A.; Utzurrum, R. C. B. and Gonzales, P.C. (1999): Mammalian diversity on Mount Isarog, a threatened center of endemism on Southern Luzon Island, Philippines. Chicago: Field Museum of Natural History, Fieldiana-Zool. 95:1-62.

Johnson, P. T. (1960): The sucking lice (Anoplura) of Egypt. I. Species infesting rodents. J. Egypt. Publ. Health Assoc. 35 (6): 203-244.

Masan, P. and Stanko, M. (2005): Mesostigmatic mites (Acari) and fleas (Siphonaptera) associated with nests of moundbuilding mouse, Mus spicilegus Petényi, 1882 (Mammalia, Rodentia). Acta. Parasitologica. 50 (3): 228-234. 
Nava, S.; Lareschi, M. and Voglino, D. (2003): Interrelationship between ectoparasites and wild rodents in Buenos Aires Province, Argentina. Mem. Inst. Oswaldo Cruz . 98:45-9.

Nowack, S. (1991): Biology of Rattus norvegicus. In: Rattus norvegicus. USA: United States Depart. of Agri., Agri. Service Cen. 1991:9-12.

Parola, P.; Cornet, J. P. ; Sanogo, Y. O. and Miller, R.S. (2003): Detection of Ehrlichia spp. Anaplasma spp. Rickettsia spp., and other eubacteria in ticks from the Thai-Myanmar border and Vietnam. J. Clint. Microbial. 41: 1600-8.

Parola, B.; Davoust and Raoult, D.(2005): Tick and flea borne emerging zoonoses. Vet. Res. 36: 469-92.

Petney, T. N.; Kolonin, G. V. and Robbins, R. G. (2007): Southeast Asian ticks (Acari: Ixodida): a historical perspective. Parasitol Res 2007; 101 (suppl 2):

Raoult, D. and Roux, V. (1997): Rickettsioses as paradigms of new or emerging infectious diseases. Clin. Mic. Robiol. Rev. 10: 694-719..

Rehbein, S.; Visser, M. and Winter, R. (2003): Productivity effects of bovine mange and control with ivermectin. Vet. Parasitol. 114: 267-84.

Salazar, N. P. (1977): Commensal rodents and their parasites in Manila and suburbs. Manila, Philippines: Proceedings of the Regional Training Seminar of Field Rat Control and Research. Nat. Res. Counc. Philippines (NRCP) Res Bull. 32:93-126.

Salibay, C. C.( 2004): Serology and histopathology of Toxoplasma gondii infection in Mus musculus (Linnaeus) experimentally-exposed to the parasites obtained from chronicallyinfected Rattus norvegicus (Erxleben) and Rattus rattus mindanensis (Mearns) caught in Dasmariñas, Cavite, Philippines. Manila, Philippines: De La Salle University,. 186 pp. Dissertation.

Salibay, C. C. and Claveria F. C. (2005): Serologic detection of Toxoplasma gondii infection in Rattus spp collected from three different sites in Dasmarinas, Cavite, Philippines. Southeast Asian J Trop. Med Public Health .36 (suppl 4):46-9.

Saluzzo, J. F. and Dodet, B. (1999): Emergence and Control of rodent-borne viral Diseases. Elsevier Science, Paris: 23-38.

Sanchez, F. F.; Benigno, E. A, and Hoque, M. M. (1985): Rodent biology and control with special reference to the Philippines. Los Baños, Laguna: National Crop Protection Center, College of Agriculture, And University of the Philippines: $151 \mathrm{pp}$.

Shoukry,A.; Morsy,T. A. and Farahat,A. A. (1987): Arthropod-ectoparasites of rodents trapped in Ismailia Governorate. Egypt. J. Egypt. Soc.Parasit., 17(2):525-538.

Singleton, G. R.; Lyn, H.; Charley, K. and Dave, S. (2003): Rats, mice and people: An interwoven relationship. Rodent Biology and Management. ACIAR. Monograph No. 96, 564p.

Soliman, S.; Main, A. J.; Marzouk, A.S.and Montasser, A. A. (2001a): Seasonal studies on commensal rats and their ectoparasites in a rural area of Egypt: the relationship of ectoparasites to the species, locality, and relative abundance of the host. J. Parasitol. 87:545-53.

Soliman, S.; Marzouk, A. S.; Main, A. J. and Montasser, A. A. (2001b): Effect of sex, size, and age of commensal rat hosts on the infestation parameters of their ectoparasites in a rural area of Egypt. $J$ Parasitol 2001b; 87:1308-16

Soulsby, E...J.L. (1982): Helminths, Arthropods and protozoans of domesticated animals. $7^{\text {th }}$ ed. Philadelphia: Lea and Febiger, 1982:809 pp. 
Uilenberg, G. (1995): International collaborative research: significance of tick-borne haemoparasitic diseases to world animal health. Vet. Parasitol. 57: 19-41.

Urceuhart, G. M.; Armour,J.; Duncan, J. L.; Dunin, A. M. and Jennings, F. W. (1994): Veterinary Parasitology. Longman \& Scientific Technical, p164.

Walker, A. (1994): The arthropods of humans and domestic animals. A guide to preliminary identification. London: Chapman and Hall, 1994:224 pp.

\title{
ARABIC SUMMARY
}

\section{الطفيليات الخارجية التى تصيب الفئر ان بمنطقتى مسطرد وبهتيم فى محافظة القليوبية}

\author{
قسم علم الحيو ان ـ كلية العلوم للبنين- جحمد كريمة الأز هر - مدينة نصر القاهرة
}

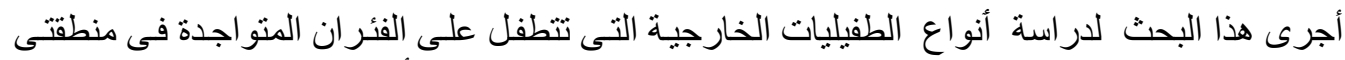

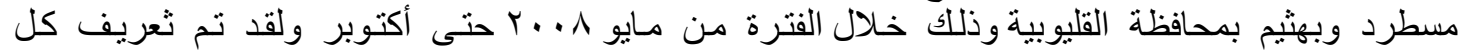

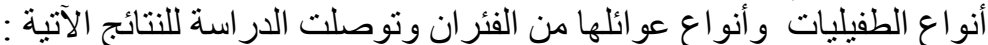

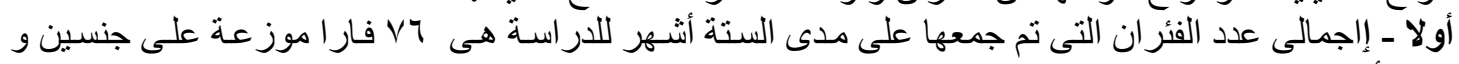

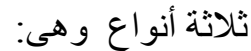

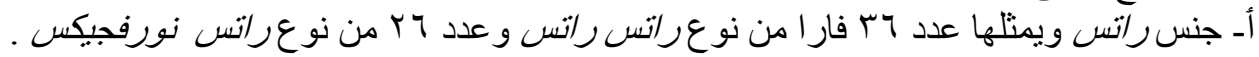

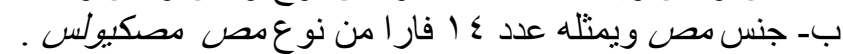

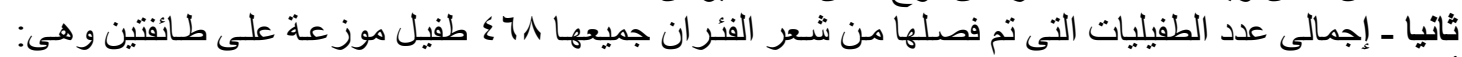

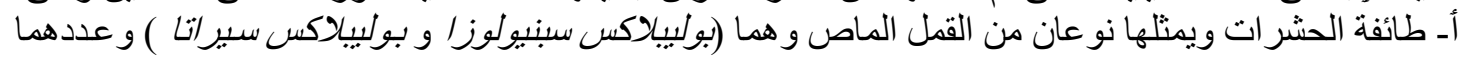

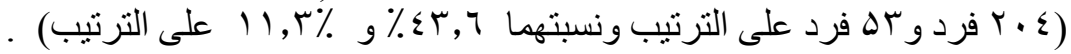

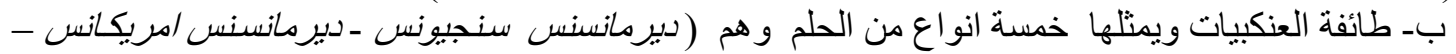

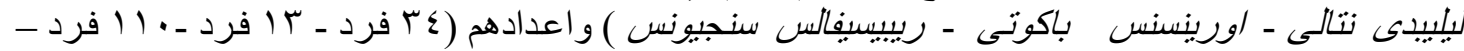

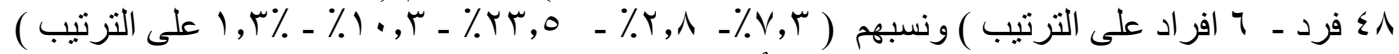

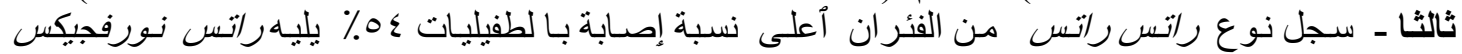

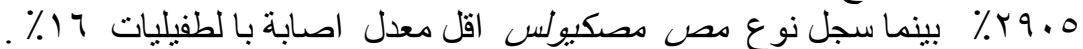

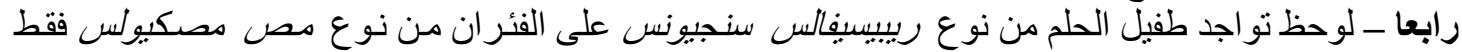

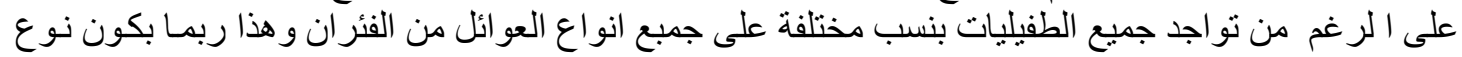

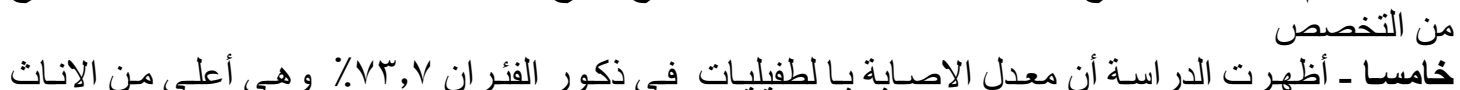

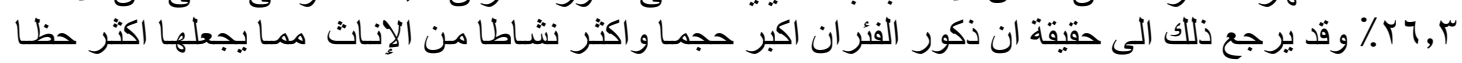

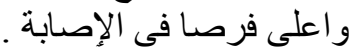

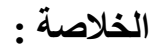

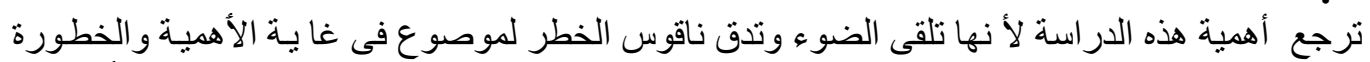

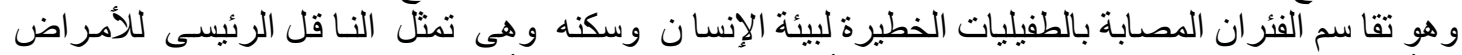

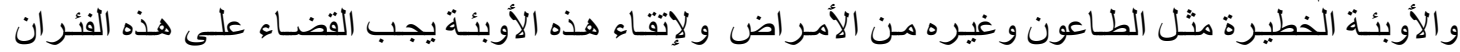

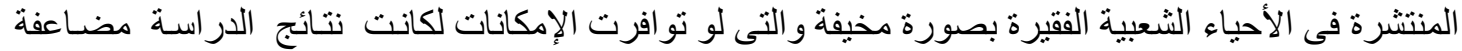

